\title{
Maritime Community Systems Economic and Changes Around the Area Industry
}

\author{
Sulsalman Moita, Mulyadi Bintaha ${ }^{1}$ \\ ${ }^{1}$ Doctoral Student of Sosiology, State University of Makassar, (Indonesia)
}

\begin{abstract}
This research investigated the institution economic system of Bajo fisherman around PT Antam Industry area at Mandiodo Village Molawe sub district and wish to express what changes is at the institution economic system of Bajo fisherman around PT. Antam.Research executed in County side of Mandiodo of sub district Molawe sum up the informant and key informant research 15 people. Data collected by using observation participate, and interview the. Technique analyses the data that is analyses qualitative. The Result of research show changed in the institution economic system of Bajo fisherman around PT. Antam industry area at Mandiodo village Molawe sub district are; economic behavior in individually, advantaged economic opportunity in temporary, new infrastructure knowledge in technology principle, economic connection pattern in complex.
\end{abstract}

Keywords: Economic Institutions, Bajo Fishermen, Change, Industrial.

\section{Introduction}

Every human life has a system with institutions that regulate the life of his generation, so as to survival for long periods of time. Existence, they developed a culture as a vehicle to solve various problems in life. As part of a social community, the maritime community has its own characteristics and patterns of life than other people whose existence is influenced by land area. Characteristic of the maritime community who depend on the marine life allows them to perform adaptasai in a long time, so that they can exist up to now. One of the maritime community in Southeast Sulawesi, which has its own characteristics in the management of the marine environment is Bajo fishing community. Bajo people inhabit the islands and shores of beaches in almost every district in Southeast Sulawesi.

Bajo can be classified as indigenous people because they are not sedentary life, and living on remote islands that cause them isolated from other people. And say retarded, because they are less untouched by development outcomes are implemented (Tasman, 2005). In carrying out the activities of daily life, Bajo fishing community has a system of beliefs, values, customs, social and economic institutions, and behaviors that have been instituted by generations. And most of the inherited system explains the existence of the Bajo as skilful seamen, who controlled marine resources to describe their lives.

One form of Bajo fishing activity life to be examined in this study, is the exclusivity of their livelihood as fishing. Bajo people have traditional economic system that has been passed down from generation to generation. For the Bajo economic institutions not only provide guidance in maritime activities but also gives basic creation patterns of social and familial relationships in life together.

Since 2012, the village became the location Mandiodo PT Antam establishment engaged in the marble industry, sea cucumber and seaweed cultivation. The presence of these industries least able to change the dynamics of the economy to economic Bajo communities around the industrial area. One of them is a means of transportation.

In addition, the presence of industry in the region Mandiodo can cause changes in the economic institutions of the Bajo fishing community fishing activities to other livelihoods, such as labor, trade, transportation, and so on. Such changes will have an impact on increasing family income and economic efforts to meet social needs. Based on the above, this study wanted to learn about the system of economic institutions and changes Bajo fishing community around the industrial area of PT. Antam in the Village District of Molawe Mandiodo Konawe North. Maritime community seringali also referred to fishing communities or the public beach, has a living standard that is typical of other communities. Characteristic that stands out is their dependence on the sea and fish as a source of their livelihood.

\section{Theoritical Framework}

According Wahyono (2000), is a fishing community living communion that is human engagement with the feeling of unity and awareness along with the sea as a natural area to bolster the existence of their lives. While David Hume (in Mubyarto, 1987) states that the fishing community is a society that covers all individuals who interact with each other by making the seas as a source in their unite territorially, customs, social, and 
economic. Based on these two concepts/terms above, then the maritime community with its conditions are generally still use the rules or mechanisms of natural in order to survive hell in fulfilling their various life dayto-day life.

Before assessing the existence of economic institutions in the fishing activities of fishing communities, the first known definition of institutions. The term social institutions points to the existence of elements that regulate the behavior of citizens. Koentjaraningrat (in Soekanto, 1990) said that social order is a system of behavior and relationship-centered activities to meet the specific needs complexes in people's lives. The existence of social institutions in general economic maritime community has in common with the economics of social institutions, to other people, but there are specific values that reflect on their identity as the people who made the sea and the waters as a source of their livelihood.

The study Kusnadi (2002), suggests that, socio-economic classification of fishing communities can be viewed from three perspectives. First, in terms of mastery of the means of production or fishing equipment, fishing community structure is divided into the categories of fishermen owner (means of production) and fishing workers. Secondly, in terms of the level of capital investment scale of its business, the structure of fishing communities are divided into categories of large and small fishermen fishing. Third, in the light of the level of technological equipment fishing, fishing communities fall into the category of modern fishing and traditional fishing. Modern fishermen using more advanced capture technology than traditional fishing. The number of fishermen is relatively small compared to the modern traditional fishermen. The differences are presenting any implications on income level and ability or socio-economic welfare.

Further review of aspects of the dynamics of the maritime community, most of livelihood as fishermen (fishing activities). Fishing activity is divided into two parts, namely the offshore fishing activity and fishing activity a pond or ponds. In carrying out fishing activities, fishing organizations have recognized that the structure consists of a retainer and mustard. The working relationship between the retainer and the mustard that has shaped the social system involving fishing communities and certain family groups join in a fishing business (Haafiz, 1980).

Retainer is the owner of the boat or motor boat, and sawinya are workers whose duties aboard fishing boats and drive the motor. The mustard family is taken from the element itself, and some of the elements that have the skills sailors at sea. Retainer in the context of social stratification has a prominent position for them as well as business owners, as well as well as a leader, both at sea and on land. Based on the writings of Pelaras (1984) showed that they can be a retainer has the following criteria: have economic wealth as boat ownership, has exemplary leadership that can be followed by the sawinya, has pangalaman and knowledge of the oceans and how to solve problems in marine, has a considerable age with a degree of Hajj and respected in the community.

The relationship between the retainer and mustard actual judging of his time working is very temporary (seasonal) but because of the mustard family is not a large part, also had considered his own family, then their relationship has become a permanent harmonious. Retainer leadership has apparently imitating the Japanese management system. Because of all this organization considers Collards are theirs and all the tools used in the company maintained it as his own. Based on the above, shows that the system of economic institutions in the maritime community over institutional strengthening of the links between the owners of capital/facilities with workers (sailors). This relationship has been forged informally for a long time which indicates the existence of the maritime community as a group of people who depend on the sea.

The origin of the Bajo until now this has not been evident since the advent of various opinions both from Bajo people themselves (traditional elders) or (community Bone), then the people who had been stranded by the Bugis Bone describes as To Bajo (shadow- shadows), because they always seemed like a shadow (Taewa, 1995).

Furthermore, the origin of the Bajo also expressed by anthropologist Unhas AbuHamid (in Djamil, 2001) that the origin of the Bajo, including the nation's Proto-Malays (Melayu Tua) is a maritime people of Funan kingdom, a kingdom of Funan giant sea lane.

\section{Method}

This research was conducted in the village Mandiodo Molawe District of North Konawe on the basis that: the region in addition to a large part of society inhabited by Bajo, also the trend of changes in economic institutions after the entry of the PT industry. Antam. Changes in the system of economic regulation will also affect changes in other aspects of life.

Informants in this study is the Bajo fishing community living around the industrial area of PT. Antam. Research informants purporsif determined via tail assessment, as well as contact and determine who will be the informant. Because this study was a qualitative study, the number of research informants is not a major requirement, but the most important is the quality of the data and information collected. Determination of informants based on the informant's ability to answer the research problem. 
To obtain the data validity and rehabilitation, also needed key informants (key informant). Existence of key informants in addition to providing information about the specific conditions the object under study also provides data on informants interviewed / examined. Number of key informants in this research planned four people, each village head Mandiodo, 2 Bajo community leaders, and Director of PT. Antam.

The study intends to capture primary data and secondary data. For the purposes of the data collection is done by observation, participatory observation, in-depth and structured interviews. While the secondary data in the form of either a research report that has been or has not been published and the data from the government office where the study took place.

This study used a qualitative analysis techniques, the capability approach to rationality in logic. In principle, by adhering to the principles of qualitative pronsip, then the process of data collection and data analysis performed together during the research process, because at the time of data collection also indirectly has been a process of data analysis and interpretation. That is to analyze the data that has been categorized, interpretative understading done, namely to interpret or give meaning to the data collected.

\section{Results And Discussion}

\section{a. System Bajo Fishermen Community Economic Institutions in Industrial Area Around Mandiodo PT} Antam Village District of Molawe.

Existence of institutions for the maritime community in general has much in common with other institutions in society, but there are specific values that reflect their identity as the people who made the sea and the waters as a source of their livelihood. Assessment system of economic institutions in the village of Bajo fishing community Mandiodo described as follows:

\section{Economic Institutions in the System of Environmental Family Bajo}

Bajo fishing community in the village Mandiodo generally recognize nuclear family, the family consisting of husband, wife and children. There is also in part the use pattern of extended family (extended family) is a family consisting of: father, mother, children, grandparents, women-in-law, in-laws and so on. Pattern nuclear family (nuclear family) for the Bajo people, in addition to reflecting the cultural communities with specific cultural values also indicate the economic institutions that regulate and distribute the economic obligations between family members. Economic system in the family Bajo occurs naturally and is informal, ie an institution that is inherited from generation to generation and are familial relationship patterns.

Economically position uwwa (father) in the life of the Bajo is a role and act as the head of the family is responsible for making a living, while the wife as homemaker is responsible for regulating the economy, maintaining the household welfare, and education of children. Furthermore, the position of the child is to follow all the advice and instruction of parents and dutiful to parents in the form of help both in fishing activities and in household activities. Fishing activity is work that socialized to boys.

In view of the Bajo community, the existence uwwa (father) described as the pillar of the house. Pole is what will hold the home of the danger of wind, waves, decay, and damaged. That is the position you are looking for a living, then he should be responsible to support their family members.

Culturally, a man who is ready to marry with a degree uwwa (fathers) are those who are able and have the experience of the sea and all its contents. Besides the ability to catch fish and other seafood is a symbol of the responsibility of a uwwa in his family. Thus the position uwwa in Bajo society economically is the backbone of the family in meeting their daily needs. Additionally father role in distributing economic values to other family members.

\section{Economic Institutions in the System of Social Life The Bajo}

In general category in the village of Bajo fishermen are fishing offshore Mondiodo. In implement their fishing activities using an informal institution that fishing relations system based on kinship and adjacency pedigree. In addition there is also a pattern by binding employment relationship provides support retainer (ship owner) and mustard (the crew).

- System Institutions Fishing by Asaz Kinship

Traditional system of economic institutions for communities in Bajo fishing, fishing activity reveal the process of cooperation among relatives and the closeness of residence. This system has been going on for generations and is an institution that affects the formation of the other institutions.

Based on the results obtained, there are two tipologo, patterns of relationship (cooperation) among relatives economy in fishing that involves 3-5 Bajo fishermen where each has a ship; and patterns of fishing cooperation involving 5-8 people Bajo fishing where one person acts as the leader and usually have larger ships.

At first the pattern of relationships indicates the position in the Bajo fishermen fishing activity is equivalent to no leadership (pamathana). There are no agreed rules regarding the sharing system. They are only concerned asama work in both the sea and the fishing activities in the sea to avoid hazards, such as storms or waves. 
The pattern of relations in the fishing activity above, also affect other areas of life. With the proximity of their residential properties helping each other in everyday life, for example, in building a house, repairing damaged houses, lending money to relatives in need, and so on.

Furthermore, the same pattern of fishing that involves 5-8 people Bajo fishermen, has a system of economic institutions are slightly different from the first pattern. At least there is an element of leadership, the distribution of the catch and the division of duties during the voyage.

\section{- System Institutions Relationship Based Arrests retainer and Collards}

Retainer fishing organization structure and mustard are patterns that make up a working relationship with the fisherman social system involving citizens and certain family groups join in an offshore fishing business.

Retainer is the owner of the boat or motor boat, and sawinya are workers whose duties aboard fishing boats and drive the motor. The mustard family is taken from the element itself, and some of the elements that have the skills sailors at sea. Retainer in the context of social stratification has a prominent position for them as well as business owners, as well as well as a leader, both at sea and on land.

Criterion referenced researchers to give status to the relevant retainer is: have the economic wealth as boat ownership, has exemplary leadership that can be followed by the sawinya, having an experience and knowledge of the sea and how solbe the problems at sea, sufficient age have with the title of Haji and respected in the community.

Retainer relationship patterns and mustard in a fishing activity is relatively more formal because each bound by treaties and rules agreed before fishing. Seoarang retainer task is to provide a motor boat, fishing equipment, and the provision of food for sea, and the retainer sometimes go sailing. While the task is to catch fish and mustard steer the fishing boat. Mustard greens are running a special for motor boats are relatively more reliable so mememiliki notch better than mustard or crew.

In general reward system that is used in the village Mandiodo sharing system as it is considered fair to good for the retainer and mustard. The assumption when given daily wage pattern, it can sometimes be a disadvantage if the retainer catches less collards, mustard greens and vice versa for the daily wage system can be detrimental if it catches quite a lot.

\section{b. Changes Occurring in Community Economic Institutions System Bajo Fishermen Around Industrial Zone PT. Antam Village Mandiodo Molawe District of North Konawe}

Study the changes that occur in the system of economic institutions in the Bajo fishing community around the industrial area, based on the results of the study do not occur in a holistic manner that covers all structures, institutional arrangements and traditional economy based Bajo.

PT. Antam's operating in 2002, is a company engaged in the processing of marble and seaweed. Prior to the company's operations, access to the village is generally reached by using sea transportation. Road connecting the village Mandiodo with neighboring villages can only be passed by a two-wheeler. Along with the entry of this company, then opened roads are passable road transport four-wheeled vehicles. This condition causes the transportation access not only benefit the company, but also especially the Bajo fishing community and the interrelation of economic activity with the surrounding community.

Referring to the above considerations, be some aspects of the economic system value changes after the entry of the PT. Antam namely:

\section{Changes in Individual Economic Behavior}

Individual economic behavior changes based on the existence of alternative economic activity. In the period before the entry of the PT. Antam, the family's economic activity takes place in homogeneous, ie all members of the family have the same economic responsibility through maritime or fishing activities. But after the entry of the PT. Antam, at least partially influence economic activity family members.

Based on the results obtained in the village Mandiodo that changes in economic behavior generally occurs among housewives and teenagers (youth). Head of the family or the husband still maintains that fishing activity is a form of hereditary culture.

In addition the option to work as an employee of PT. Antam to mothers in Mandiodo, in addition to due to job opportunities, especially prepared by the owners of the company for women, is also the issue of the identity of most value provide opportunities for women to be equal with men. The assumption, if during the Bajo women often regarded as a symbol of domestication, which is more oriented household activities but after the employment opportunities of PT. Antam, economic rights relative has publicly distributed between men and women. 


\section{Utilization of Economic Opportunity In Temporary}

The entry of a moving company PT Antam dipengolahan pearls and seaweed has at least been given the opportunity to scavenge bagimasyarakat about economic opportunities. The economic opportunities not only for those who have the skill or skills, but also people who are interested in jobs that require physical labor and prime power.

Based on the results of the study showed that the majority of adult men who work in the Bajo PT Antam only work on a temporary basis, which is done when the dry season arrives. Bad season for fishing in Mandiodo and surrounding Bajo is the season when the west wind, the wind is not favorable for the Bajo fishermen who characterized the big waves, tide, weather and high waves, and storm winds that accompanied the great sea.

In this season rarely fishermen fishing in offshore areas, as well as marine hazards and also catches fish and the sea is less. Fishermen only catch fish only in the result seaside least to meet consumption needs.

In order to fill the vacant time during the lean season, Bajo fishing community in Mandiodo many activities that perform valuable economic and non-economic. Prior to the entry of PT Antam, Bajo fishermen seek mangroves for firewood purposes, making or repairing places pickling fish, making or repairing boats, home repair participate in social activities at the Bajo communities, and so on.

The results also revealed that the expectations of the people of Bajo in Mandiodo that company PT Antam exist, because of the many advantages that can be obtained for the local people, such as access roads, the rise of motorcycle transport business, the growth of nine basic stalls, food stalls around the company, and so on .

\section{Knowledge-Based Prasana New Economy Technology}

The introduction of a new economic system starts from a hypothesis that still traditional society, the tendency is also using the technology that is conventional in meeting their needs. The same condition is also experienced by people in the village of Bajo fishermen Mandiodo. Society, in addition to not knowing the type and how to use new technologies, as well as the technology used during fishing activities still rely on their ancestral heritage. The presence of PT Antam since 2002 has implications for access to open areas extensively. The implication, Mandiodo society, in addition to already know the new technologies in the field of maritime also know and understand the new technology-based industries.

The introduction of new technologies in the field of maritime very realistic considering the effort developed by PT Antam is managing marble, sea cucumbers and sea grass, thus requiring technologies, such as large motor boats, equipment to identify the source and location of pearls, pearl exploration equipment to take on the seabed, equipment for sorting out the proper raw materials chosen, the equipment for breeding sea grass, and so on.

\section{Pattern of Economic Activity Complex Relationship}

Assessment system of economic institutions also explain the pattern of relationships between economic actors. The pattern of this relationship describes the forms of economic roles, the distribution division of roles, interactions that occur in economic activities, obligations and responsibilities, as well as the implications arising from the relationship, among other leadership patterns, profits, use of facilities, and so on.

In the Bajo tribe communities in the District Molawe Mandiodo village, the pattern of economic relations as described above also occur, although the form, manner and mechanism is relatively simple to do. In the past the relations in economic activity in the region is largely done through the activity of fishing waters.

Some patterns of economic activity relationships can be explained to describe the lives of people who are relatively traditional Bajo, among others, economic cooperation among family members. Father, son and nephew are both run fishing activities.

Shape the pattern of traditional relationships also comprises the activities of fishing cooperation between neighbors and close relatives. They generally form small groups whose members are about five to seven people. Some of the most prominent thing on the pattern of these relationships include: cooperation in catching fish, collaboration in addressing ocean storms, and distribution of fish catches are fair

Retainer relationship patterns and mustard on Bajo fishing community in Mandiodo also explain the implications arising from the relationship, ie the rights and obligations. The mustard is obliged to assist the retainer in fishing on the high seas and then to assert their rights in the form of salary received, whether daily wages or salary month.

Furthermore, the pattern of relationships also occur without a permanent contract bond. Here, the company provides an opportunity for the community to work with a daily wage. Based on the results obtained, Bajo communities in Mandiodo many are pleased with the working relationship like this pattern, for reasons directly earn a wage; which can spent for daily needs. 


\section{Conclusions}

The results showed that the system of economic institutions Bajo fishing community around the industrial area in the village of PT Antam Mandiodo Molawe District of North Konawe, describe the values of the specific and exclusive nature that reflects their identity as a maritime community. The values that are specific, among others: a. system of economic institutions in a family environment Bajo which explains the position and role of family members in the fishing activity; b. system of economic institutions in social life which explain the Bajo fishing arrests regulation system based asaz good kinship between close relatives or between neighbors, in a system based regulation of fishing retainer relationships and mustard; and c. income and exchange systems.

The changes that occur in the system of economic institutions in the Bajo fishing community around the industrial area of PT Antam Village District of Molawe Mandiodo among others: changes in individual economic behavior, namely the existence of an alternative economic option but to work as fishermen turn to work as an employee of PT Antam; exploiting economic opportunities that are filled on a temporary basis to work in a time when famine PT Antam arrest; knowledge-based new economy infrastructure technology, namely the introduction of changes in technology and the use of technology from traditional to modern technologies, such as the use of motor boats, infrastructure managers pearl, seaweed, transportation infrastructure, and so on; and by a complex relationship of economic activity, ie the change in the pattern of relationships which are homogeneous pattern of relationships amongst people Bajo turned into a more heterogeneous changes both from the aspect of space, time and dynamics of the aspects of the relationship.

[1]. Djamil, Abd. Rachman, 2001. Pola Kehidupan Sosial Ekonomi Masyarakat Suku Bajo di Kecamatan Lainea Kabupaten Kendari Kendari (Laporan Penelitian). Unhalu Kendari.

[2]. Haafiz, AR 1980. Kelompok-Kelompok Punggawa-Juragan-Sawi suatu Telaah. Leplit Unhas. Ujung pandang.

[3]. Harsojo. Introduction to Anthropology. Bandung. Bina Reserved, 1988.

[4]. William A. Haviland.,1995. An Introduction to Anthropology, Second Edition; New York: The Mac Millan.

[5]. Hendropuspito. 1989. Sosiologi Agama. BP Gunung Mulya. Jakarta.

[6]. Himes and Moore, J. 1978. Study of Sociology. Scott Foresman. Atlanta.

[7]. Horridae, Adrian, 1980. "The Prahu", Traditional Sailling Of Indonesia. Oxpord University Press. Singapore.

[8]. Kasim, Syarifuddin. , 2003. Karakteristik Pola Kehidupan Sosial Ekonomi Nelayan Setelah Proses Restelment Di Wilayah Daratan (Studi Di Desa Torobulu Kecamatan Kolono Kabupaten Konawe Selatan Sultra). Hasil Penelitian LPIU Due-Like Unhalu yang belum dipublikasikan.

[9]. Koentjaraningrat, 1990. Kebudayaan, Mentalitas dan Pembangunan. Penerbit Gramedia Pustaka Utama. Jakarta.

[10]. Koentjaraningrat, 1985. Pengantar Ilmu Antropologi. Aksara Baru. Jakarta.

[11]. Kusnadi. , 2002. Fishermen Social Conflict, Poverty and the seizure of Fisheries Resources. LKIS. Yogyakarta

[12]. Kusnadi, 2002. Poverty and Diversification Work among the Fishermen. Working Paper Series No 4 December. Center for the Study of Communication Beach. Jember.

[13]. Lauer, Robert H., 1993. Perspektif Tentang Perubahan Sosial. PT Rineka Cipta. Jakarta.

[14]. Mashuri, 1989. Menyusuri Pantai Utara. Tira Pustaka. Jakarta.

[15]. Mubyarto, 1987. Nelayan Dan Kemiskinan. Gramedia. Jakarta.

[16]. Moleong, lexy J, 1996. Qualitative Research Methodology. Teens Rosdakarya. Bandung.

[17]. Nontji, Anugerah, 2001. Laut Nusantara. Djambatan. Jakarta.

[18]. Pelaras, Cristian, 1984. Patron-Client Relationships In Society Bugis-Makassar.

[19]. Soekanto. Soerjono, 1990. Sosiologi Suatu Pengantar. CV Rajawali. Jakarta.

[20]. Soelaiman, M. Munandar, 1998. Dinamika Masyarakat Transisi, Mencari Alternatif Teori Sosiologi dan Arah Perubahan. Pustaka Pelajar. Yogyakarta.

[21]. Spradley, James P, 2000. Metode Etnografi (Pengantar Dr. Amri Marzali, MA). PT/ Tiara Wacana. Yogyakarta.

[22]. Suyanto, Bagong, 1993. Motorization and Commercialization Fisheries Impact on Income Level Changes, Revenue Sharing, and the emergence of social polarization in Economics and Modern Among Traditional Fishermen. YIIS-The Toyota Foundation. Jakarta.

[23]. Tasman, Taewa, 2005. Sistem Kepercayaan dan Perilaku Masyarakat Nelayan Bajo dalam Aktifitas Penangkapan Ikan (Studi Pada Masyarakat Nelayan Bajo di Kecamatan Lasolo Kab. Konawe). Hasil Penelitian LPIU Deu-Like Unhalu Tahun 2005, dan dipublikasikan pada majalah terakreditas "Sosial Politi” FISIP Unhalu Edisi Desember 2005.

[24]. Wahyono, Ary, dkk, 2000. Hak Ulayat Laut Dikawasan Timur Indonesia. Media Pressindo. Yogyakarta. 